\title{
Use of sexed semen and its effect on conception rate, calf sex, dystocia, and stillbirth of Holsteins in the United States
}

\author{
H. D. Norman, ${ }^{1}$ J. L. Hutchison, and R. H. Miller \\ Animal Improvement Programs Laboratory, Agricultural Research Service, USDA, Beltsville, MD 20705-2350
}

\begin{abstract}
Use of sexed semen for artificial insemination of US Holstein heifers (1.3 million breedings) and cows (10.8 million breedings) in Dairy Herd Improvement herds was characterized by breeding year, parity, service number, region, herd size, and herd milk yield. Sexed semen was used for $1.4,9.5$, and $17.8 \%$ of all reported breedings for 2006, 2007, and 2008, respectively, for heifers, and for $0.1,0.2$, and $0.4 \%$, respectively, for cows. For 2008 sexed semen breedings, 80.5 and $68.6 \%$ of use was for first services of heifers and cows, respectively. For cows, $63.1 \%$ of 2008 sexed semen use was for first parity. Mean sexed semen use within herd was the greatest for heifers in the Southwest $(36.2 \%)$ and for cows in the Mideast (1.3\%). Mean sexed semen use increased for heifers but changed little for cows as either herd size or herd mean milk yield increased. Availability of sexed semen was examined for Holstein bulls in active AI service; of 700 bulls born after 1993, 37\% had sexed semen marketed by mid August 2009. Active AI bulls with marketed sexed semen were superior to average active AI bulls for evaluations of yield traits, productive life, somatic cell score, daughter pregnancy rate, service-sire calving ease, service-sire stillbirth, final score, sire conception rate, and lifetime net merit. The effect of sexed semen use on conception rate, calf sex, dystocia, and stillbirth also was examined for heifers and cows. Mean conception rate for heifers was $56 \%$ for conventional and $39 \%$ for sexed semen; corresponding conception rates for cows were 30 and $25 \%$. For single births from sexed semen breedings, around $90 \%$ were female. Dystocia and stillbirth were more frequent for heifers (6.0 and $10.4 \%$, respectively, for conventional semen; 4.3 and $11.3 \%$, respectively, for sexed semen) than for cows $(2.5$ and $3.6 \%$, respectively, for conventional semen; 0.9 and $2.7 \%$, respectively, for sexed semen). Difficult births declined by $28 \%$ for heifers and $64 \%$ for cows with sexed semen use. Stillbirths were more
\end{abstract}

Received September 30, 2009.

Accepted March 29, 2010.

${ }^{1}$ Corresponding author: Duane.Norman@ars.usda.gov prevalent for twin births except for sexed semen heifer breedings. Stillbirths of single male calves of heifers were more frequent for breedings with sexed semen $(15.6 \%)$ than conventional semen (10.8\%); a comparable difference was not observed for cows, for which stillbirth frequency of single male calves even decreased (2.6 vs. $3.6 \%)$. Overall stillbirth frequency was reduced by sexed semen use for cows but not for heifers.

Key words: sexed semen, conception rate, dystocia, stillbirth

\section{INTRODUCTION}

Breeders have tried to manipulate the sex of offspring at conception for centuries (Garner and Seidel, 2008). Research with rabbits was successful in producing a large deviation from the traditional near-equal ratio of male to female offspring by measuring DNA content of individual sperm using fluorescence while sperm were processed through a flow cytometer (Johnson et al., 1989). Many bovine field studies (e.g., Seidel et al., 1999; Seidel and Schenk, 2002; Seidel, 2003; DeJarnette et al., 2009) reported around $90 \%$ female offspring had been achieved by separating X- and Y-bearing sperm. Further research and technical improvements led to the introduction of sexed semen by US commercial organizations in 2005 (Weigel, 2004; Cassell, 2005; DeJarnette, 2005; DeJarnette et al., 2009).

The process of sorting sperm cells reduces conception rates. Seidel and Schenk (2002) reported results of several field trials. In Holstein and Jersey trials in 3 states, pregnancy rate for sexed semen averaged 31 to $42 \%$ compared with 43 to $62 \%$ for conventional semen; in an additional Holstein trial with large herd differences in fertility, pregnancy rate ranged from 21 to $35 \%$ for sexed semen compared with $58 \%$ for conventional. DeJarnette et al. (2009) reported that sexed semen conception rates for daughters of bulls marketed by one AI organization averaged 47,39 , and $32 \%$ for services 1,2 , and $\geq 3$, respectively, for heifers and 26,30 , and $27 \%$, respectively, for cows. For Brown Swiss and Red Holsteins in Switzerland, pregnancy rates at 30 to 40 $\mathrm{d}$ after sexed semen breeding were $33 \%$ for heifers and $28 \%$ for cows (Bodmer et al., 2005). Cerchiaro et al. 
(2007) reported a mean pregnancy rate of $51 \%$ from sexed semen for a Holstein field study in Italy. Olynk and Wolf (2007) modeled net present value for sexed semen use with conception rates for sexed semen that were 53,75 , or $90 \%$ of those for conventional semen and reported sexed semen use was profitable only if its conception rate was $\geq 90 \%$ of that of conventional semen. Schenk et al. (2009) reported that sexed semen use reduced pregnancy rates for cows by $>12$ percentage units. The lower conception rate and higher cost of sexed semen has led to its use primarily for nulliparous heifers and first services for which the expected number of offspring per unit of sexed semen used is the highest (Seidel, 2007; DeJarnette et al., 2008, 2009).

Several studies have explored the potential economic benefits of sexed semen use to produce female calves. In an early projection, Van Vleck (1981) estimated that sexed semen use could be profitable at a maximum cost of $\$ 19$ per unit based on a price of $\$ 6$ per unit for conventional semen; he also estimated that the rate of genetic progress could increase by $15 \%$ with widespread use of sexed semen. Seidel (2003) concluded that generally a premium of $\leq \$ 10$ for sexed semen with near normal fertility would be needed to achieve widespread economic usefulness and pointed out that profitability from sexed semen use would vary according to dairy industry conditions. Sexed semen use may increase to solve a shortage of replacement dairy heifers but may decrease once the shortage is corrected. Such conditions usually follow increases in producer milk prices. Sexed semen use also can help to avoid biosecurity problems from purchasing replacements outside the herd (Seidel, 2003; Weigel, 2004). The added cost of a unit of sexed semen was estimated to be $\$ 30$ to $\$ 46$ in 1999 (Amann, 1999 ) and $\$ 30$ to $\$ 35$ in 2005 (Cassell, 2005; DeJarnette, 2005). The extra cost of sexed semen over conventional is currently around $\$ 20$ per dose in the United States (G. E. Seidel Jr., Colorado State University, Fort Collins, CO; personal communication).

Ettema et al. (2007) modeled use of sexed semen for Danish industry conditions and concluded that profitable application of sexed semen was possible. However, market price of replacement animals would be affected, which directly affects the profitability from sexed semen use. Abdel-Azim and Schnell (2007) simulated use of sexed semen in a US Holstein commercial herd over $20 \mathrm{yr}$ and reported a large genetic advantage from its use. Relative genetic superiority of first-parity cows would increase to $>30 \%$ in yr 11 but then decline to $9 \%$ in yr 20.

DeVries et al. (2008) explored the effect of sexed semen use on the US dairy industry. They suggested that dairy producers obtain dairy replacement heifers from only genetically superior dams. They reported that sexed semen use was expected to increase the rate of genetic progress (but not $>15 \%$ ) as well as the supply of herd replacements to where current demand was exceeded and replacement prices were lowered. The long-term predictions were accelerated herd expansions, increased milk supply, lower milk prices, and lower production costs.

Few studies have examined the differences in dystocia and stillbirth incidence for dairy cattle when female and male calves are produced from conventional and sexed semen. Seidel (2003) and Weigel (2004) reported that the higher frequency of female calves from sexed semen and consequently smaller calf size would be expected to reduce the incidence of dystocia, especially for nulliparous heifers. Tubman et al. (2004) reported least squares means for calving ease scored from 1 (no assistance) to 4 (delivery by caesarian section) of 1.15 for female calves and 1.30 for male calves based on trials with mostly beef heifers and cows; differences between least squares means for conventional and sexed semen (1.23 and 1.22 , respectively) were not significant $(P=$ $0.87)$. They also reported nonsignificantly different $(P$ $>0.10$ ) neonatal death (born dead or died within 24 $\mathrm{h}$ of birth) rates of 4.0 and $3.5 \%$ for conventional and sexed semen, respectively, and 4.5 and $3.0 \%$ for female and male calves. For a Danish field trial with Holstein heifers, Borchersen and Peacock (2009) reported stillbirth (born dead or died within $24 \mathrm{~h}$ ) rates of $10 \%$ for female calves and $14 \%$ for male calves from sexed semen breedings compared with 12 and $20 \%$ from conventional semen. DeJarnette et al. (2009) found that mean incidence of stillbirths for Holstein heifers with female calves was $9.2 \%$ for sexed semen breedings and $10.5 \%$ for conventional semen. They reported that herd, calving season within herd, and sire within semen type (sexed or conventional) influenced stillbirth; they also noted a higher incidence of stillbirths when male calves were born from a 90\% X-sorted sperm population ( $20 \%$ compared with $13 \%$ for conventional semen) and speculated that this possibly resulted from the sorting process selecting aneuploid Y-bearing sperm. Herd, calving season within herd, calving age, sire within semen type, and interaction of semen type and calving age all affected the stillbirth rate for Holstein heifers with male calves.

The objectives of this study were to summarize the extent of sexed semen use for US Holsteins in DHI herds based on breeding year, parity, service number, region, herd size, and herd milk yield. Merit for traits of economic importance was compared between all active AI Holstein bulls and those with sexed semen marketed. The effect of use of conventional and sexed semen on heifer and cow conception rate, calf sex, dystocia, and stillbirth was also examined. 


\section{MATERIALS AND METHODS}

Holstein records for AI breedings with sexed and conventional semen were extracted from the USDA national dairy database (Beltsville, MD) and included National Association of Animal Breeders (Columbia, MO) marketing codes (500 series) or format-5 reproductive record codes (Animal Improvement Programs Laboratory, 2009). Format-5 reproductive records are supplied to the national database primarily from 3 dairy records processing centers: AgSource Cooperative Services (Verona, WI), AgriTech Analytics (Visalia, CA), and Dairy Records Management Systems (Raleigh, NC, and Ames, IA). Those 3 processing centers provided records for more than 1.5 million and 12.1 million breedings of heifers and cows, respectively. Records with marketing code 514 were not included as sexed semen breedings because the technology used by the AI organization differed from that used by other AI organizations. Each breeding was determined to have a known outcome (success or failure) based on a subsequent calving date or reproductive event (heat, a later breeding, or pregnancy check). Herd requirements included conception rate between 10 and 90\%, reported breedings for $\geq 50 \%$ of milking cows each year, and AI use of $\geq 80 \%$ to reduce the likelihood of including herds that reported only successful breedings or herds with low-quality recording. Not all breedings were recorded on farms, and not all recorded breedings were sent to USDA, particularly for heifers. However, codes for semen type were assumed to be reliable and thus the percentage of sexed semen used to be accurate. Only breedings from January 2006 through December 2008 for parities 1 through 5 and services 1 through 7 were included. Excluding parities $>5$ and service numbers $>7$ eliminated 1.2 and $1.6 \%$ of breedings, respectively. The final data set included 1.3 million breedings for heifers and 10.8 million breedings for cows.

Frequency and percentage of sexed semen use were derived by parity and service number. Percentage of herds using sexed semen for breeding heifers and cows within 7 regions of the United States: Mideast (Delaware, Kentucky, Maryland, North Carolina, Tennessee, Virginia, and West Virginia), Midwest (Illinois, Indiana, Iowa, Michigan, Minnesota, Missouri, Ohio, and Wisconsin), Mountain-Prairie (Colorado, Kansas, Montana, Nebraska, North Dakota, South Dakota, Utah, and Wyoming), Northeast (Connecticut, Maine, Massachusetts, New Hampshire, New Jersey, New York, Pennsylvania, Rhode Island, and Vermont), Northwest (Alaska, Idaho, Oregon, and Washington), Southeast (Alabama, Arkansas, Florida, Georgia, Louisiana, Mississippi, Oklahoma, Puerto Rico, South Carolina, and Texas), and Southwest (Arizona, California, Hawaii,
Nevada, and New Mexico) as defined by Hare et al. (2004) were derived as well as percentage of use within those herds. Corresponding information was derived for 5 herd size groups $(\leq 50,51-100,101-500,501-1,000$, and $\geq 1,001$ cows $)$ and 5 herd milk yield groups $(\leq 8,000$, $8,001-9,500,9,501-11,000,11,001-12,500$, and $\geq 12,501$ $\mathrm{kg}$ ). The GLM procedure of SAS (SAS Institute, 2004) was used with the following linear fixed effects model to explain the percentage of sexed semen used for cow and heifer breedings:

$$
\mathrm{y}_{\mathrm{ijk} k \mathrm{mn}}=\mathrm{BY}_{\mathrm{i}}+\mathrm{P}_{\mathrm{j}}+\mathrm{S}_{\mathrm{k}}+\mathrm{R}_{\mathrm{l}}+\mathrm{HS}_{\mathrm{m}}+\mathrm{HM}_{\mathrm{n}}+\mathrm{e}_{\mathrm{ijklmn}} \text {, }
$$

where $\mathrm{y}$ is semen type defined as 0 (conventional) or sexed (1) for service $\mathrm{k}$ (1 through 7) for an animal bred in year i (2006 through 2008) and with parity j (1 through 5 ) in a herd of size $\mathrm{m}$ ( 5 groups) and milk yield $\mathrm{n}$ (5 groups) in region $\mathrm{l}$ (7 regions); BY is breeding year; $\mathrm{P}$ is parity; $\mathrm{S}$ is service number; $\mathrm{R}$ is region; $\mathrm{HS}$ is herd size; HM is herd milk yield; and e is residual. Heifer and cow breedings were analyzed separately because data were more readily available for cows than for heifers; effect of parity was excluded for modeling heifer breedings. A binomial model for individual breedings was chosen to allow determination of factors that might have been important when a dairy producer decided on semen type (conventional or sexed) for a breeding.

To investigate concern by semen purchasers that bulls with the highest genetic merit often did not have sexed semen available, marketing status of semen from the 700 active AI Holstein bulls born after January 1, 1994, was examined. Percentage of bulls with sexed semen marketed by the release of official USDA-DHIA evaluations in mid August 2009 was derived for each lifetime net merit decile. August 2009 USDA-DHIA evaluations for yield (milk, fat, and protein), productive life, SCS, daughter pregnancy rate, service-sire calving ease, service-sire stillbirth, final score (supplied by Holstein Association USA Inc., Brattleboro, VT), sire conception rate, and lifetime net merit as well as expected future inbreeding were compared between the 260 bulls with marketed sexed semen and the 700 bulls with conventional semen grouped by tercile (i.e., bottom, middle, or top third) for each trait.

Breedings were coded as successful (evidence of pregnancy) or unsuccessful as described by Norman et al. (2009). Conception rates were derived from all breedings. A successful breeding and subsequent calf from animals enrolled in the dystocia recording program were required for the record to be included in the analysis of the effect of sexed semen use on calf sex, dystocia score, and stillbirth; therefore, fewer observations were available for those traits: $319,736(24.6 \%)$ heifer and 1,272,673 (11.8\%) cow calvings for calf sex 
Table 1. Factors affecting percentage of sexed semen used for 1.3 million heifer and 10.8 million cow breedings of US Holsteins in DHI herds from 2006 through 2008

\begin{tabular}{|c|c|c|c|c|c|}
\hline \multirow[b]{2}{*}{ Effect $^{1}$} & \multirow[b]{2}{*}{ df } & \multicolumn{2}{|c|}{ Heifer breedings } & \multicolumn{2}{|c|}{ Cow breedings } \\
\hline & & SS & $F$-value & SS & $F$-value \\
\hline Breeding year & 2 & $50,204,037$ & 31,836 & 139,552 & 3,280 \\
\hline Parity & 4 & - & - & 115,231 & 1,354 \\
\hline Service number & 4 & $23,194,586$ & 7,354 & 166,212 & 1,953 \\
\hline Region & 6 & $1,425,818$ & 301 & 75,033 & 588 \\
\hline Herd size & 4 & $9,950,169$ & 3,155 & 21,580 & 254 \\
\hline Herd milk yield & 4 & 420,501 & 133 & 24,789 & 291 \\
\hline
\end{tabular}

${ }^{1}$ All effects significant at $P<0.0001$.

and dystocia and 319,720 (24.6\%) heifer and 1,036,298 $(9.6 \%)$ cow calvings for stillbirth. Dystocia was defined as births that were reported as requiring considerable force (4) or extremely difficult (5) for calving difficulty score rated on a 1 to 5 scale (Van Tassell et al., 2003). Stillbirth was defined as a calf that was born dead or died within $48 \mathrm{~h}$.

The VARCOMP procedure of SAS (SAS Institute, 2004) was used to determine fixed effects of herd-breeding year, parity (for cows), service number, and semen type (conventional or sexed) on conception rate and calf sex. Because of computer memory limitations, conception rate was analyzed using a random data sample based on herd code, which included 90 and $48 \%$ of herd-years and 50 and $2 \%$ of breeding records for heifers and cows, respectively. Least squares means for conception rate also were calculated for the complete data set using a model with breeding year, service number, and semen type but not herd. The same fixed effects along with calf sex were examined for their influence on dystocia and stillbirth. Again, heifer and cow breedings were analyzed separately because performance differed greatly between heifers and cows for some traits. A combined analysis would have resulted in a distorted reflection of the importance of parity because the ratio of heifers to cows for the data set differed from the ratio for the US Holstein DHI population.

\section{RESULTS AND DISCUSSION}

All factors examined for their effect on percentage of sexed semen used for heifer and cow breedings (Table $1)$ were significant $(P<0.0001)$. Not surprisingly, breeding year had the largest type-III $F$-values because commercial marketing of sexed semen began in 2006 and expanded rapidly. The factor with the next largest $F$-value was service number for both heifer and cow breedings. Herd size was a moderate contributing factor for heifers, as was parity for cows.

Distribution of heifer and cow breedings by service number, breeding year, and semen type is shown in
Table 2. Sexed semen was used for 1.4, 9.5, and $17.8 \%$ of all heifer breedings reported for 2006, 2007, and 2008, respectively, and $0.1,0.2$, and $0.4 \%$ of all cow breedings, respectively. The much higher percentage of sexed semen use for heifers could be the result of research and commercial recommendations that sexed semen be used for breeding heifers rather than cows because of higher conception rates (DeJarnette et al., 2009) and greater genetic superiority for heifers compared with cows. Percentages of heifer breedings with sexed semen for each service increased over time for all service numbers. For 2008 heifer breedings, sexed semen use was $24.0 \%$ for first service, $11.6 \%$ for second service, and $5.0 \%$ for third service.

Trends in 2008 sexed semen breedings by service number for cows (Tables 2 and 3) were similar to those for heifers. Sexed semen use decreased as service number increased for all parities. For each service across parities (Table 3), sexed semen use was $68.6 \%$ for first service, $20.0 \%$ for second service, $6.6 \%$ for third service, and $2.8 \%$ for fourth service. For the first 4 parities across services, sexed semen use was $63.1 \%$ for first parity compared with 20.7, 9.8, and $4.4 \%$ for second, third, and fourth parities, respectively. Almost $75 \%$ of sexed semen cow breedings were for first and second services during the first 2 parities. For all 2008 cow breedings (conventional and sexed semen; Tables 2 and 3 ), sexed semen use was $0.7 \%$ for first service, $0.3 \%$ for second service, and $0.2 \%$ for third service and $0.7 \%$ for first parity, $0.3 \%$ for second parity, and $0.2 \%$ for third, fourth, and fifth parities.

Percentages of herds using sexed semen for heifer and cow breedings by region in 2008 are shown in Table 4 . The Southwest had the highest percentage $(76.9 \%)$ of herds using sexed semen for heifer breedings as well as the highest mean use of sexed semen within herd $(36.2 \%)$. For cow breedings, the Mideast had the highest percentage of herds using sexed semen (15.4\%) and the highest mean use within herd (1.3\%). For both heifer and cow breedings, the Northwest had the lowest mean use within herd $(10.9 \%$ for heifers and $<0.1 \%$ 
Table 2. Distribution of US Holstein heifer and cow breedings in DHI herds from 2006 through 2008 by service number, breeding year, and semen type

\begin{tabular}{|c|c|c|c|c|c|c|c|c|c|}
\hline \multirow[b]{3}{*}{ Service no. } & \multirow[b]{3}{*}{ Breeding year } & \multicolumn{4}{|c|}{ Heifer breedings } & \multicolumn{4}{|c|}{ Cow breedings } \\
\hline & & \multicolumn{2}{|c|}{$\begin{array}{l}\text { Conventional } \\
\text { semen }\end{array}$} & \multicolumn{2}{|c|}{ Sexed semen } & \multicolumn{2}{|c|}{ Conventional semen } & \multicolumn{2}{|c|}{ Sexed semen } \\
\hline & & $\mathrm{n}$ & $\%$ & $\mathrm{n}$ & $\%$ & $\mathrm{n}$ & $\%$ & $\mathrm{n}$ & $\%$ \\
\hline \multirow[t]{3}{*}{1} & 2006 & 267,419 & 98.3 & 4,727 & 1.7 & $1,172,063$ & 99.9 & 1,523 & 0.1 \\
\hline & 2007 & 242,554 & 87.5 & 34,776 & 12.5 & $1,637,368$ & 99.7 & 5,002 & 0.3 \\
\hline & 2008 & 208,128 & 76.0 & 65,879 & 24.0 & $1,636,605$ & 99.3 & 11,091 & 0.7 \\
\hline \multirow[t]{3}{*}{2} & 2006 & 86,269 & 99.2 & 669 & 0.8 & 639,606 & $>99.9$ & 299 & $<0.1$ \\
\hline & 2007 & 92,889 & 94.6 & 5,273 & 5.4 & $1,035,901$ & 99.8 & 1,606 & 0.2 \\
\hline & 2008 & 97,363 & 88.4 & 12,799 & 11.6 & $1,042,480$ & 99.7 & 3,238 & 0.3 \\
\hline \multirow[t]{3}{*}{3} & 2006 & 28,562 & 99.6 & 123 & 0.4 & 343,493 & $>99.9$ & 93 & $<0.1$ \\
\hline & 2007 & 35,903 & 97.5 & 936 & 2.5 & 631,844 & 99.9 & 661 & 0.1 \\
\hline & 2008 & 41,997 & 95.0 & 2,211 & 5.0 & 643,207 & 99.8 & 1,069 & 0.2 \\
\hline \multirow[t]{3}{*}{4} & 2006 & 10,000 & 99.8 & 23 & 0.2 & 182,507 & $>99.9$ & 29 & $<0.1$ \\
\hline & 2007 & 14,547 & 98.3 & 246 & 1.7 & 377,066 & 99.9 & 299 & 0.1 \\
\hline & 2008 & 17,477 & 96.5 & 632 & 3.5 & 389,474 & 99.9 & 453 & 0.1 \\
\hline \multirow{3}{*}{$\geq 5$} & 2006 & 5,434 & 99.9 & 8 & 0.1 & 173,242 & $>99.9$ & 18 & $<0.1$ \\
\hline & 2007 & 10,039 & 98.9 & 109 & 1.1 & 430,184 & $>99.9$ & 211 & $<0.1$ \\
\hline & 2008 & 12,607 & 97.7 & 291 & 2.3 & 449,753 & 99.9 & 318 & 0.1 \\
\hline \multirow{3}{*}{ All } & 2006 & 397,684 & 98.6 & 5,550 & 1.4 & $2,510,911$ & 99.9 & 1,962 & 0.1 \\
\hline & 2007 & 395,932 & 90.5 & 41,340 & 9.5 & $4,112,363$ & 99.8 & 7,779 & 0.2 \\
\hline & 2008 & 377,572 & 82.2 & 81,812 & 17.8 & $4,161,519$ & 99.6 & 16,169 & 0.4 \\
\hline
\end{tabular}

for cows). Because only a single sexed semen mating was required for a herd to be designated as using sexed semen, regions associated with large herds might be expected to have a higher percentage of herds with sexed semen breedings than those with small herds. Across all regions, 34.2 and $10.6 \%$ of herds used sexed semen for heifer and cow breedings, respectively, in 2008; mean sexed semen use within herd was 17.8 and $0.4 \%$ for heifer and cow breedings, respectively, nationally. The reason for differences between regions was not obvious.

Percentages of herds using sexed semen for heifer and cow breedings by herd size are shown in Table 5 .
Percentage of herds with sexed semen breedings generally increased as herd size increased: from 17.2 and $4.5 \%$ for herds with $\leq 50$ animals to 72.4 and $18.0 \%$ for herds with $\geq 1,001$ animals for heifer and cow breedings, respectively. The exception was a slightly larger percentage $(21.5 \%)$ of cow breedings with sexed semen for herds with 501 to 1,000 animals. Mean sexed semen use within herd also increased (6.0 to $25.9 \%$ ) for heifer breedings as herd size increased. In contrast, mean sexed semen use for cow breedings changed little as herd size increased.

Table 5 also shows herd percentages of cow and heifer breedings with sexed semen by herd mean milk yield.

Table 3. Percentages of 16,169 sexed semen breedings of US Holstein cows in DHI herds in 2008 by service number and parity and percentages of total breedings for which sexed semen was used by service number and parity

\begin{tabular}{|c|c|c|c|c|c|c|c|}
\hline \multirow[b]{2}{*}{ Statistic } & \multirow[b]{2}{*}{ Service no. } & \multicolumn{6}{|c|}{ Parity } \\
\hline & & 1 & 2 & 3 & 4 & 5 & All \\
\hline \multirow[t]{6}{*}{ Sexed semen breedings, $\%$} & 1 & 45.4 & 13.3 & 6.1 & 2.6 & 1.2 & 68.6 \\
\hline & 2 & 11.6 & 4.5 & 2.4 & 1.1 & 0.4 & 20.0 \\
\hline & 3 & 3.5 & 1.6 & 0.8 & 0.5 & 0.2 & 6.6 \\
\hline & 4 & 1.5 & 0.8 & 0.3 & 0.1 & 0.1 & 2.8 \\
\hline & $\geq 5$ & 1.0 & 0.5 & 0.2 & 0.1 & 0.1 & 2.0 \\
\hline & All & 63.1 & 20.7 & 9.8 & 4.4 & 2.0 & 100.0 \\
\hline Total breedings for which sexed & 1 & 1.2 & 0.4 & 0.3 & 0.3 & 0.3 & 0.7 \\
\hline \multirow[t]{5}{*}{ semen was used, $\%$} & 2 & 0.5 & 0.2 & 0.2 & 0.2 & 0.1 & 0.3 \\
\hline & 3 & 0.2 & 0.1 & 0.1 & 0.1 & 0.1 & 0.2 \\
\hline & 4 & 0.2 & 0.1 & 0.1 & 0.1 & 0.1 & 0.1 \\
\hline & $\geq 5$ & 0.1 & 0.1 & 0.0 & 0.0 & 0.1 & 0.1 \\
\hline & $\bar{A} l l$ & 0.7 & 0.3 & 0.2 & 0.2 & 0.2 & 0.4 \\
\hline
\end{tabular}


Table 4. Percentages of herds using sexed semen for breeding heifers and cows in 2008 for US DHI Holstein herds and mean sexed semen use within herd by region

\begin{tabular}{lccccc}
\hline & \multicolumn{2}{c}{ Herds using sexed semen, $\%$} & & \multicolumn{2}{c}{ Mean sexed semen use within herd, ${ }^{2} \%$} \\
\cline { 2 - 3 } \cline { 5 - 5 } Region $^{1}$ & Heifers & Cows & & Heifers & Cows \\
\hline Mideast & 46.8 & 15.4 & & 24.3 & 1.3 \\
Midwest & 32.4 & 12.7 & & 18.2 & 0.4 \\
Mountain-Prairie & 39.6 & 10.9 & & 20.5 & 0.3 \\
Northeast & 33.8 & 7.2 & & 15.7 & 0.5 \\
Northwest & 50.0 & 9.5 & & 10.9 & $<.1$ \\
Southeast & 45.7 & 10.6 & & 36.2 & 0.6 \\
Southwest & 76.9 & 34.2 & 17.8 & 0.1 \\
United States & 34.2 &
\end{tabular}

${ }^{1}$ Mideast $=$ Delaware, Kentucky, Maryland, North Carolina, Tennessee, Virginia, and West Virginia; Midwest = Illinois, Indiana, Iowa, Michigan, Minnesota, Missouri, Ohio, and Wisconsin; Mountain-Prairie = Colorado, Kansas, Montana, Nebraska, North Dakota, South Dakota, Utah, and Wyoming; Northeast = Connecticut, Maine, Massachusetts, New Hampshire, New Jersey, New York, Pennsylvania, Rhode Island, and Vermont; Northwest $=$ Alaska, Idaho, Oregon, and Washington; Southeast = Alabama, Arkansas, Florida, Georgia, Louisiana, Mississippi, Oklahoma, Puerto Rico, South Carolina, and Texas; Southwest = Arizona, California, Hawaii, Nevada, and New Mexico (Hare et al., 2004).

${ }^{2}$ Weighted by total number of breedings in herd.

As herd mean yield increased from $\leq 8,000$ to $\geq 12,501$ $\mathrm{kg}$, the percentage of herds using sexed semen increased from 14.0 to $55.6 \%$ for heifer breedings and from 5.6 to $22.9 \%$ for cow breedings. Mean sexed semen use within herd increased (6.8 to 20.8\%) for heifer breedings as herd mean yield increased. However, mean sexed semen use for cow breedings changed little as herd mean yield increased (i.e., more herds used sexed semen for cow breedings as herd mean yield increased, but the higher producing herds did not use sexed semen more frequently for breeding cows). No reason for the differing practice between breeding heifers and cows in relation to herd mean milk yield was obvious.

Of the 700 active AI Holstein bulls born in January 1994 or later, $37 \%$ had sexed semen marketed at some time by the release of August 2009 USDA-DHIA evaluations. Percentages of bulls with marketed sexed semen for the low to high deciles for lifetime net merit were $14,17,26,27,27,47,47,55,45$, and 58. The 5 lowest deciles for lifetime net merit (percentiles 0 to 49) had the lowest percentages of bulls with marketed sexed semen (14 to 27\%). The 5 highest deciles (percentiles 50 to 99 ) had 45 to $58 \%$ of bulls with marketed sexed semen. Although sexed semen was not marketed for all the top bulls for lifetime net merit, more than twice as many bulls in the top 50 percentiles had sexed semen marketed compared with those below percentile 50 .

Mean August 2009 USDA-DHIA evaluations for 700 active AI Holstein bulls by trait and type of marketed semen are shown in Table 6. Bulls with sexed semen were superior to an average active AI bull with conventional semen for every trait, with PTA advantages of $75 \mathrm{~kg}$ for milk, $3.0 \mathrm{~kg}$ for fat, $1.9 \mathrm{~kg}$ for protein, 1.1 mo for productive life, 0.04 for SCS, 0.5 percent-

Table 5. Percentages of herds using sexed semen for breeding heifers and cows in 2008 for US DHI Holstein herds and mean sexed semen use within herd by herd size and herd mean milk yield

\begin{tabular}{|c|c|c|c|c|}
\hline \multirow[b]{2}{*}{ Trait } & \multicolumn{2}{|c|}{ Herds using sexed semen, $\%$} & \multicolumn{2}{|c|}{ Mean sexed semen use within herd, ${ }^{1} \%$} \\
\hline & Heifers & Cows & Heifers & Cows \\
\hline \multicolumn{5}{|l|}{ Herd size, n } \\
\hline$\leq 50$ & 17.2 & 4.5 & 6.0 & 0.4 \\
\hline $51-100$ & 27.3 & 9.7 & 8.6 & 0.5 \\
\hline $101-500$ & 49.8 & 15.8 & 16.7 & 0.5 \\
\hline $501-1,000$ & 70.7 & 21.5 & 21.9 & 0.3 \\
\hline$>1,001$ & 72.4 & 18.0 & 25.9 & 0.3 \\
\hline \multicolumn{5}{|c|}{ Herd mean milk yield, $\mathrm{kg}$} \\
\hline$\leq 8,000$ & 14.0 & 5.6 & 6.8 & 0.5 \\
\hline$\overline{8}, 001-9,500$ & 21.4 & 6.9 & 10.8 & 0.5 \\
\hline $9,501-11,000$ & 35.5 & 11.4 & 16.6 & 0.4 \\
\hline $11,001-12,500$ & 49.2 & 15.2 & 20.0 & 0.3 \\
\hline$\geq 12,501$ & 55.6 & 22.9 & 20.8 & 0.4 \\
\hline
\end{tabular}

${ }^{1}$ Weighted by total number of breedings in herd. 
Table 6. Mean August 2009 USDA-DHIA evaluations for 700 active AI Holstein bulls grouped into terciles by trait and type of marketed semen

\begin{tabular}{lccccc}
\hline & \multicolumn{4}{c}{ Conventional semen } & \\
\cline { 2 - 5 } Evaluation trait & Bottom third & Middle third & Top third & All & Sexed semen \\
\hline PTA milk, kg & 50 & 429 & 732 & 404 & 479 \\
PTA fat, kg & 3.9 & 15.6 & 27.3 & 15.6 & 18.6 \\
PTA protein, kg & 3.6 & 12.8 & 21.4 & 12.6 & 14.5 \\
PTA productive life, mo & -1.4 & 0.9 & 3.4 & 1.0 & 2.1 \\
PTA SCS & 2.78 & 2.95 & 3.13 & 2.95 & 2.91 \\
PTA daughter pregnancy rate, $\%$ & -1.9 & -0.6 & 1.1 & -0.5 & 0.0 \\
PTA service-sire calving ease, ${ }^{1}$ DBH $\%$ & 5.9 & 8.5 & 11.2 & 8.5 & 7.4 \\
PTA service-sire stillbirth, $\%$ & 6.8 & 7.8 & 9.0 & 7.9 & 7.7 \\
PTA final score & 0.85 & 1.85 & 2.73 & 1.81 & 1.83 \\
Sire conception rate, $\%$ & -1.0 & 1.2 & 3.1 & 1.1 & 1.6 \\
Lifetime net merit, $\$$ & 100 & 262 & 438 & 267 & 363 \\
Expected future inbreeding, $\%$ & 4.85 & 5.66 & 6.13 & 5.55 & 5.70 \\
\hline
\end{tabular}

${ }^{1}$ Percentage of difficult births observed for first-parity heifers.

age units for daughter pregnancy rate, 1.1 percentage units for service-sire calving ease, 0.2 percentage units for service-sire stillbirth, and 0.02 units for final score. They also had a superiority of 0.5 percentage units for sire conception rate and $\$ 96$ for lifetime net merit. Mean expected future inbreeding was slightly higher (0.15 percentage units) for bulls with sexed semen than for the average active AI bull, but reduced milk yield or performance in other traits because of that increase would be small. For example, lifetime milk yield would decrease by $72 \mathrm{~kg}$ for registered cows and $28 \mathrm{~kg}$ for grades based on the inbreeding depressions reported for US Holsteins by Smith et al. (1998). A more comprehensive examination is needed to determine the full effect of sexed semen use on genetic improvement.

Results from the SAS VARCOMP analyses (SAS Institute, 2004) are shown in Table 7. Semen type had a large effect on heifer conception rate. As expected, semen type was the most important determinant of calf sex. Service number also affected calf sex for heifer breedings, as did parity for cow breedings. The $F$-values for heifer service number and cow parity may have been affected by confounding with semen type. Cow service number and parity, which had similar $F$-values, had greater effect than semen type on conception rate. For dystocia and stillbirth, calf sex accounted for the most variation for both heifers and cows. Service number also was associated with cow stillbirth: mean stillbirth rate for cows increased from $3.4 \%$ for first service to $4.5 \%$ for services $\geq 5$. The relationship between service number and cow stillbirth probably is associated with overconditioning due to a long lactation and dry period (although dry period length was not examined). DeJarnette et al. (2009) reported that month-year within herd and herd had the greatest effect on conception rate for Holstein heifers and that herd and season within herd had the largest effects on stillbirth incidence.
Phenotypic (arithmetic) and least squares means for heifer conception rate by semen type and service number are shown in Table 8. Least squares means for heifers generally were identical to arithmetic means for conception rate. Overall mean conception rate for Holstein heifers was $56 \%$ for conventional semen and $39 \%$ for sexed semen, which indicated that sexed semen was only $70 \%$ as fertile for heifer breedings as conventional semen. Differences in conception rate between breedings with sexed and conventional semen have varied among other studies: for example, $59 \%$ for conventional and $33 \%$ for sexed semen in Switzerland (Bodmer et al., 2005), 56 and 45\%, respectively, in the United States (DeJarnette et al., 2009), and 62 and 49\%, respectively, in Denmark (Borchersen and Peacock, 2009), with sexed semen 56, 80, and $79 \%$ as fertile as conventional semen in Switzerland, the United States, and Denmark, respectively. The data used by DeJarnette et al. (2009) were primarily a subset of data used in this study.

Mean conception rate for first-service breedings (Table 8) was $59 \%$ for conventional semen and $41 \%$ for sexed semen. Conception rate declined as service number increased for both semen types. Difference between heifer conception rates for sexed semen and conventional semen breedings ranged from 14 to 20 percentage units for service numbers 1 through $\geq 5$. First-service conception rate for sexed semen breedings was only $69 \%$ as high as that for conventional semen breedings; corresponding percentages were $63 \%$ for second and third services and $62 \%$ for fourth and fifth (or more) services.

Phenotypic (arithmetic) and least squares means for cow conception rate by semen type, parity, and service number are shown in Table 9. Similar to heifers, least squares means for cows were almost identical to arithmetic means for conception rate. Overall mean cow conception rate was $30 \%$ for conventional semen and $25 \%$ 
Table 7. Factors affecting conception rate, calf sex, dystocia, and stillbirth for US Holstein heifer and cow breedings in DHI herds from 2006 through 2008

\begin{tabular}{|c|c|c|c|c|c|c|c|}
\hline Trait & Model effect ${ }^{1}$ & \multicolumn{3}{|c|}{ Heifer breedings } & \multicolumn{3}{|c|}{ Cow breedings } \\
\hline \multirow[t]{4}{*}{ Conception rate ${ }^{2}$} & Herd-year & 21,371 & $12,379.00$ & 2.47 & 21,417 & $6,951.30$ & 1.64 \\
\hline & Parity & - & - & - & 4 & 60.23 & 75.95 \\
\hline & Service no. & 4 & 209.40 & 222.81 & 4 & 65.32 & 82.37 \\
\hline & Semen type & 1 & $1,296.96$ & $5,520.13$ & 1 & 4.63 & 23.37 \\
\hline \multirow[t]{2}{*}{ Calf sex } & Herd-year & 10,890 & $5,644.34$ & 2.03 & 20,685 & $11,947.00$ & 1.65 \\
\hline & Semen type & 1 & $1,438.93$ & $5,640.21$ & 1 & 186.87 & 533.45 \\
\hline \multirow[t]{5}{*}{ Dystocia } & Herd-year & 10,890 & $2,139.08$ & 4.04 & 20,685 & $2,568.38$ & 5.77 \\
\hline & Parity & - & - & - & 4 & 0.43 & 5.04 \\
\hline & Service no. & 4 & 0.20 & 1.02 & 4 & 4.33 & 50.32 \\
\hline & Semen type & 1 & 1.47 & 30.25 & 1 & 0.24 & 10.93 \\
\hline & Calf sex & 2 & 115.79 & $1,191.86$ & 2 & 64.53 & $1,498.45$ \\
\hline Stillbirth & Herd-year & 10,890 & $1,805.25$ & 1.86 & 20,685 & $1,500.71$ & 2.07 \\
\hline
\end{tabular}

${ }^{1}$ All effects significant at $P<0.0001$ except for service number for cow calf sex $(P=0.1875)$, heifer dystocia $(P=0.3953)$, and heifer stillbirth $(P=0.6626)$ and semen type for cow $(P=0.0689)$ and heifer $(P=0.0264)$ stillbirth .

${ }^{2}$ Based on a random data sample because of computer memory limitations; 90 and $48 \%$ of herd-years and 50 and $2 \%$ of breeding records included for heifers and cows, respectively.

${ }^{3}$ Mean stillbirth rate was $3.4,3.7,4.0,4.1$, and $4.5 \%$ for services $1,2,3,4$, and $\geq 5$, respectively.

for sexed semen; sexed semen conception rate was $83 \%$ as high as that for conventional semen breedings. The difference of 5 percentage units between conventional and sexed semen conception rate was much less than the pregnancy rate difference ( $>12$ percentage units) reported by Schenk et al. (2009) for Holsteins with pregnancies confirmed by palpation ( $38 \%$ for conventional semen and 24 to $25 \%$ for sexed semen breedings). Conception rate across services generally declined as parity increased for both conventional semen (32 to $26 \%$ ) and sexed semen (27 to $21 \%$ ) breedings. Schenk et al. (2009) also reported lower pregnancy rates for sexed semen breedings as parity increased. Conception rate across parities declined similarly as service number increased: from 32 to $25 \%$ for conventional semen and from 26 to $18 \%$ for sexed semen. The decline in conception rate associated with parity increase was greater for first service than for subsequent services (9 percentage units for conventional semen and 8 percentage units for sexed semen). For conventional semen, later services had smaller declines across parities, but sexed semen conception rates showed both declines and increases as parity increased.

Based on mean overall conception rates (Table 8), 2.6 sexed semen services were needed for a heifer pregnancy but only 1.8 services with conventional semen. Similarly, based on cow conception rates (Table 9), 4.0 sexed semen services were needed for a cow pregnancy but only 3.3 with conventional semen. When the ad- ditional cost of sexed semen is considered, the higher conception rate for heifers compared with cows indicates that using sexed semen for heifer rather than cow breedings is financially preferable.

Percentages of heifer and cow breedings by calf birth status (sex and multiple birth) and semen type are shown in Table 10. Frequency of twins was around 1\% for heifers and around 5\% for cows regardless of semen type. Hossein-Zadeh et al. (2008) reported 1 and $6 \%$ twinning for Iranian Holstein heifers and cows, re-

Table 8. Mean conception rates $^{1}(\%)$ for US Holstein heifer breedings in DHI herds from 2006 through 2008 by service number and semen type

\begin{tabular}{lcc}
\hline & \multicolumn{2}{c}{ Semen type } \\
\cline { 2 - 3 } Service no. & Conventional & Sexed \\
\hline 1 & $59(59)$ & $41(41)$ \\
2 & $54(54)$ & $34(34)$ \\
3 & $49(49)$ & $31(31)$ \\
4 & $45(45)$ & $28(28)$ \\
$\geq 5$ & $37(37)$ & $23(22)$ \\
All $^{2}$ & 56 & 39 \\
\hline
\end{tabular}

${ }^{1}$ Arithmetic (phenotypic) mean followed by LSM in parentheses; LSM calculated using a model with breeding year, service number, and semen type but not herd because of computer memory limitations.

${ }^{2}$ Mean conception rate for all services was $56 \%$ for conventional semen and $32 \%$ for sexed semen in 2006, 55 and $42 \%$, respectively, in 2007 , and 56 and $39 \%$, respectively, in 2008 . 
Table 9. Mean conception rates $^{1}(\%)$ for US Holstein cow breedings in DHI herds from 2006 through 2008 by service number, parity, and semen type

\begin{tabular}{|c|c|c|c|c|c|c|c|}
\hline \multirow[b]{2}{*}{ Semen type } & \multirow[b]{2}{*}{ Service no. } & \multicolumn{6}{|c|}{ Parity } \\
\hline & & 1 & 2 & 3 & 4 & 5 & All \\
\hline \multirow[t]{6}{*}{ Conventional } & 1 & $35(35)$ & $31(31)$ & $29(29)$ & $28(28)$ & $26(26)$ & 32 \\
\hline & 2 & $33(33)$ & $31(30)$ & $30(30)$ & $28(28)$ & $27(27)$ & 31 \\
\hline & 3 & $31(31)$ & $30(30)$ & $29(29)$ & $28(28)$ & $27(27)$ & 30 \\
\hline & 4 & $28(28)$ & $28(28)$ & $28(28)$ & $26(26)$ & $26(26)$ & 28 \\
\hline & $\geq 5$ & $25(25)$ & $25(25)$ & $24(24)$ & $24(24)$ & $24(23)$ & 25 \\
\hline & All & 32 & 30 & 29 & 27 & 26 & 30 \\
\hline \multirow[t]{6}{*}{ Sexed } & 1 & $28(28)$ & $24(24)$ & $21(20)$ & $22(22)$ & $20(20)$ & 26 \\
\hline & 2 & $25(25)$ & $23(23)$ & $22(21)$ & $19(19)$ & $24(24)$ & 24 \\
\hline & 3 & $24(23)$ & $22(22)$ & $27(27)$ & $13(12)$ & $20(20)$ & 23 \\
\hline & 4 & $21(21)$ & $16(16)$ & 18 (18) & $22(22)$ & $23(22)$ & 20 \\
\hline & $\geq 5$ & $21(20)$ & $16(16)$ & $12(11)$ & $19(18)$ & $23(22)$ & 18 \\
\hline & $\bar{A} l l$ & 27 & 23 & 21 & 20 & 21 & 25 \\
\hline
\end{tabular}

${ }^{1}$ Arithmetic (phenotypic) mean followed by LSM in parentheses; LSM calculated using a model with breeding year, service number, and semen type but not herd because of computer memory limitations.

spectively. For conventional semen, slightly more single female $(50.5 \%)$ than single male $(48.5 \%)$ calves were reported to have been born to heifers but considerably fewer for cows (45.4 and $49.2 \%$, respectively). For single births from conventional semen, the female:male ratio for calf sex stayed constant for each parity at 48:52 and showed no trend as parity increased. For single births from sexed semen, a high percentage of female calves resulted (91.0\% for heifers and $89.3 \%$ for cows). Although calf sex was not reported for twin births, the percentage of female calves for sexed semen cow breedings would be about $90 \%$ if twin births from those breedings were assumed to be predominantly female as well. Tubman et al. (2004) reported $49 \%$ male calves from conventional semen and 88 and $92 \%$ sexing accuracy for $\mathrm{X}$ - and Y-sorted semen, respectively. For single births from breedings with X-bearing semen, Borchersen and Peacock (2009) and DeJarnette et al. (2009) reported 91 and $89 \%$ female calves, respectively. Earlier studies (Seidel et al., 1999; Seidel and Schenk, 2002) reported around $90 \%$ female calves from such breedings.

Percentages of births with dystocia for heifer and cow breedings by calf birth status and semen type are shown in Table 11. Dystocia was more prevalent for heifers $(6.0 \%$ for conventional semen and $4.3 \%$ for sexed semen) than for cows $(2.5 \%$ for conventional semen and $0.9 \%$ for sexed semen) when calf sex and multiple-birth status were not considered. Because sexed semen use greatly increased the percentage of female calves, it reduced the percentage of births with dystocia by $28 \%$ for heifers and $64 \%$ for cows. Dystocia also occurred more often with single male calves ( 8.0 to $8.8 \%$ for heifers; 1.2 to $3.3 \%$ for cows) than with single female calves (3.8\% for heifers; 0.9 to $1.8 \%$ for cows), which agrees with findings by Tubman et al. (2004). Although twin births are normally associated with more dystocia than are single births (Echternkamp et al., 2007; Lombard et al., 2007), heifers had less dystocia with twins (6.5\% for conventional semen and $4.4 \%$ for sexed semen) than with single male calves $(8.0 \%$ for conventional semen and $8.8 \%$ for sexed semen). The slight increase in dystocia for single male calves for heifer breedings from sexed semen compared with conventional semen may have been related to the selection of aneuploid Y-bearing sperm by the sorting process as suggested by DeJarnette et al. (2009).

Table 10. Percentages of US Holstein heifer and cow breedings in DHI herds from 2006 through 2008 by calf sex, multiple-birth status, and semen type

\begin{tabular}{lccrrrr}
\hline & \multicolumn{2}{c}{ Heifer breedings, ${ }^{1} \%$} & & \multicolumn{2}{c}{ Cow breedings, ${ }^{2} \%$} \\
\cline { 2 - 3 } \cline { 5 - 6 } Calf birth status & \multirow{2}{*}{ Conventional } & Sexed & & Conventional & Sexed \\
\hline Single female & 50.5 & 90.2 & & 45.4 & 85.1 \\
Single male & 48.5 & 8.9 & & 49.2 & 10.2 \\
Twins & 1.1 & 0.9 & & 5.5 & 4.6 \\
\hline
\end{tabular}

${ }^{1}$ With twins excluded, $51.0 \%$ of calves from heifer breedings with conventional semen were female and $49.0 \%$ were male; corresponding percentages for heifer breedings with sexed semen were 91.0 and $9.0 \%$.

${ }^{2}$ With twins excluded, $48.0 \%$ of calves from cow breedings with conventional semen were female and $52.0 \%$ were male; corresponding percentages for cow breedings with sexed semen were 89.3 and $10.7 \%$. 
Table 11. Percentages of births with reported dystocia or stillbirth for US Holstein heifer and cow breedings in DHI herds from 2006 through 2008 by calf sex, multiple-birth status, and semen type

\begin{tabular}{|c|c|c|c|c|c|}
\hline \multirow[b]{2}{*}{ Trait } & \multirow[b]{2}{*}{ Calf birth status } & \multicolumn{2}{|c|}{ Heifer breedings, \% } & \multicolumn{2}{|c|}{ Cow breedings, $\%$} \\
\hline & & Conventional & Sexed & Conventional & Sexed \\
\hline \multirow[t]{4}{*}{ Dystocia } & Single female & $3.8^{\mathrm{a}}$ & $3.8^{\mathrm{a}}$ & $1.8^{\mathrm{a}}$ & $0.9^{\mathrm{a}}$ \\
\hline & Single male & $8.0^{\mathrm{b}}$ & $8.8^{\mathrm{b}}$ & $3.3^{\mathrm{b}}$ & $1.2^{\mathrm{b}}$ \\
\hline & Twins & $6.5^{\mathrm{c}}$ & $4.4^{\mathrm{c}}$ & $4.7^{\mathrm{c}}$ & $1.3^{\mathrm{b}}$ \\
\hline & All births & 6.0 & 4.3 & 2.5 & 0.9 \\
\hline \multirow[t]{4}{*}{ Stillbirth } & Single female & $9.7^{\mathrm{a}}$ & $10.8^{\mathrm{a}}$ & $3.6^{\mathrm{a}}$ & $2.7^{\mathrm{a}}$ \\
\hline & Single male & $10.8^{\mathrm{b}}$ & $15.6^{\mathrm{b}}$ & $3.6^{\mathrm{a}}$ & $2.6^{\mathrm{a}}$ \\
\hline & Twins & $12.5^{\mathrm{c}}$ & $10.4^{\mathrm{c}}$ & $7.5^{\mathrm{b}}$ & $5.8^{\mathrm{b}}$ \\
\hline & All births & 10.4 & 11.3 & 3.6 & 2.7 \\
\hline
\end{tabular}

${ }^{\mathrm{a}-\mathrm{c}}$ Percentages within a column with different superscripts differ $(P<0.05)$.

Percentages of stillbirths for heifer and cow breedings by calf birth status and semen type are also shown in Table 11. Similar to dystocia, stillbirths were more prevalent for heifers than for cows (from 1.7 to 6.0 times as frequent within calf birth status and type of semen used for breeding), which agrees with HosseinZadeh et al. (2008). Echternkamp et al. (2007) and Hossein-Zadeh et al. (2008) found a negative relationship between fetal number and survival. In the current study, stillbirths were most frequent for twins except for sexed semen heifer breedings, which probably was the result of the lower dystocia associated with female calves. Again similar to results for dystocia, stillbirth frequency for heifer sexed semen breedings was the highest $(15.6 \%)$ for single male calves; stillbirth frequency for single male calves from heifer breedings with conventional semen was $10.8 \%$. DeJarnette et al. (2009) had reported a higher frequency of stillbirths for single male calves from heifer breedings in 25 Holstein herds ( $20 \%$ for sexed semen compared with $12 \%$ for conventional semen); however, the difference for the large data set in this study was smaller. If the higher incidence of dystocia and stillbirth for single male calves from breedings with sexed semen compared with conventional semen resulted from chromosomal differences as DeJarnette et al. (2009) speculated, surprisingly a comparable difference was not observed for cows, for which stillbirth frequency was even lower for single male calves from sexed semen breedings (2.6\%) than from conventional semen breedings (3.6\%). Stillbirth percentages for single female calves were also slightly higher $(10.8 \%)$ for sexed semen compared with conventional semen $(9.7 \%)$ for heifer breedings but were lower (2.7 and $3.6 \%$, respectively) for cow breedings. DeJarnette et al. (2009) found no difference in heifer stillbirth rate between conventional and sexed semen breedings after adjustment was made for calving age. Difference in herd recording of reproductive events also could be a possible cause for some confusion in interpreting dystocia and stillbirth results.

\section{CONCLUSIONS}

Dairy producers in the United States have begun using sexed semen extensively (34.2 and 10.6\% of herds for heifer and cow breedings, respectively), especially for animals with traditionally higher conception rates (i.e., heifers and first-service cows). Percentage of breedings with sexed semen has increased since 2006 when sexed semen became commercially available, especially for heifers $(17.8 \%$ of heifer breedings in 2008 were with sexed semen). Bulls selected to have sexed semen marketed were superior to average active AI Holstein bulls in August 2009. The rapid increase in the use of sexed semen from bulls of above-average genetic merit likely is producing larger heifer inventories and a surplus of milking animals. At times when milk supply exceeds demand, such surpluses will lower farm milk prices and lower replacement values for young animals. Conception rate for sexed semen breedings was affected negatively by sexing technology and was only 70 and $83 \%$ as great as with conventional semen for heifers and cows, respectively. Because only 2.6 sexed semen services are needed per pregnancy for heifers compared with 4.0 for cows, sexed semen should be used primarily for heifer breedings because of financial considerations. For single births, dairy producers were rewarded with 91 and $89 \%$ single female calves from heifer and cow breedings, respectively, when using female-designated sexed semen. The higher percentage of female calves led to reduced dystocia for both heifers and cows, especially for twin births. Stillbirths also were less frequent for twins when sexed semen was used. An increase in stillbirth rate for heifers was observed for single calves, especially males, with sexed semen use.

\section{ACKNOWLEDGMENTS}

The cooperation of the AgriTech Analytics (Visalia, CA), AgSource Cooperative Services (Verona, WI), and Dairy Records Management Systems (Raleigh, 
$\mathrm{NC}$, and Ames, IA) in supplying reproductive reports is acknowledged. The National Association of Animal Breeders (Columbia, MO) developed and coordinated the marketing codes used for designating type of semen used for breedings. The PTA for final score were provided by Holstein Association USA Inc. (Brattleboro, VT). Analysis suggestions from M. T. Kuhn (formerly ARS, USDA, Beltsville, MD) are greatly appreciated as is manuscript review by S. M. Hubbard (ARS, USDA, Beltsville, MD). Appreciation is also extended to G. E. Seidel Jr. (Colorado State University, Fort Collins) for suggestions before manuscript submission.

\section{REFERENCES}

Abdel-Azim, G., and S. Schnell. 2007. Genetic impacts of using female-sorted semen in commercial and nucleus herds. J. Dairy Sci. 90:1554-1563

Amann, R. P. 1999. Issues affecting commercialization of sexed sperm. Theriogenolgy 52:1441-1457.

Animal Improvement Programs Laboratory. 2009. Listing of format 5 , reproductive record. Revision 1.2. http://aipl.arsusda.gov/ formats/fmt5.html Accessed Sept. 3, 2009.

Bodmer, M., F. Janett, M. Hässig, N. den Daas, P. Reichert, and R. Thun. 2005. Fertility in heifers and cows after low dose insemination with sex-sorted and non-sorted sperm under field conditions. Theriogenology 64:1647-1655.

Borchersen, S., and M. Peacock. 2009. Danish A.I. field data with sexed semen. Theriogenology 71:59-63.

Cassell, B. 2005. Does sexed semen have a role in your breeding program? Hoard's Dairyman 150:396.

Cerchiaro, I., M. Cassandro, R. Dal Zotto, P. Carnier, and L. Gallo. 2007. A field study on fertility and purity of sex-sorted cattle sperm. J. Dairy Sci. 90:2538-2542.

De Vries, A., M. Overton, J. Fetrow, K. Leslie, S. Eicker, and G. Rogers. 2008. Exploring the impact of sexed semen on the structure of the dairy industry. J. Dairy Sci. 91:847-856.

DeJarnette, J. M. 2005. Sexed semen: Is it finally a reality? Select Sires Selections January:8-9.

DeJarnette, J. M., R. L. Nebel, and C. E. Marshall. 2009. Evaluating the success of sex-sorted semen in US dairy herds from on farm records. Theriogenology 71:49-58.

DeJarnette, J. M., R. L. Nebel, C. E. Marshall, J. F. Moreno, C. R. McCleary, and R. W. Lenz. 2008. Effect of sex-sorted sperm dosage on conception rates in Holstein heifers and lactating cows. J. Dairy Sci. 91:1778-1785.

Echternkamp, S. E., R. M. Thallman, R. A. Cushman, M. F. Allan, and K. E. Gregory. 2007. Increased calf production in cattle selected for twin ovulations. J. Anim. Sci. 85:3239-3248.

Ettema, J. F., D. L. Hoag, and G. E. Seidel Jr. 2007. Economic opportunities for sexed semen on commercial dairies. Hoard's West 9:W67-W68.
Garner, D. L., and G. E. Seidel Jr. 2008. History of commercializing sexed semen for cattle. Theriogenology 69:886-895.

Hare, E., H. D. Norman, and J. R. Wright. 2004. Duration of herd participation in Dairy Herd Improvement milk recording in the United States. J. Dairy Sci. 87:2743-2747.

Hossein-Zadeh, N. G., A. Nejati-Javaremi, S. R. Miraei-Ashtiani, and H. Kohram. 2008. An observational analysis of twin births, calf stillbirth, calf sex ratio, and abortion in Iranian Holsteins. J. Dairy Sci. 91:4198-4205.

Johnson, L. A., J. P. Flook, and H. W. Hawk. 1989. Sex preselection in rabbits: Live births from $\mathrm{X}$ and $\mathrm{Y}$ sperm separated by DNA and cell sorting. Biol. Reprod. 41:199-203.

Lombard, J. E., F. B. Garry, S. M. Tomlinson, and L. P. Garber. 2007. Impacts of dystocia on health and survival of dairy calves. J. Dairy Sci. 90:1751-1760.

Norman, H. D., J. R. Wright, S. M. Hubbard, R. H. Miller, and J. L. Hutchison. 2009. Reproductive status of Holstein and Jersey cows in the United States. J. Dairy Sci. 92:3517-3528.

Olynk, N. J., and C. A. Wolf. 2007. Expected net present value of pure and mixed sexed semen artificial insemination strategies in dairy heifers. J. Dairy Sci. 90:2569-2576.

SAS Institute. 2004. SAS OnlineDoc 9.1.2. SAS Inst. Inc., Cary, NC.

Schenk, J. L., D. G. Cran, R. W. Everett, and G. E. Seidel Jr.. 2009. Pregnancy rates in heifers and cows with cryopreserved sexed sperm: Effects of sperm numbers per inseminate, sorting pressure and sperm storage before sorting. Theriogenology 71:717-728.

Seidel, G. E. Jr. 2003. Economics of selecting for sex: The most important genetic trait. Theriogenology 59:585-598.

Seidel, G. E. Jr. 2007. Overview of sexing sperm. Theriogenology 68:443-446.

Seidel, G. E., Jr., and J. L. Schenk. 2002. Field trials with sexed, frozen bovine semen. Pages 64-69 in Proc. 19th Tech. Conf. on Artificial Insemination and Reproduction. Natl. Assoc. Animal Breeders, Columbia, MO

Seidel, G. E. Jr., J. L. Schenk, L. A. Herickhoff, S. P. Doyle, Z. Brink, R. D. Green, and D. G. Cran. 1999. Insemination of heifers with sexed sperm. Theriogenology 52:1407-1420.

Smith, L. A., B. G. Cassell, and R. E. Pearson. 1998. The effects of inbreeding on the lifetime performance of dairy cattle. J. Dairy Sci. 81:2729-2737.

Tubman, L. M., Z. Brink, T. K. Suh, and G. E. Seidel Jr. 2004 Characteristics of calves produced with sperm sexed by flow cytometry/cell sorting. J. Anim. Sci. 82:1029-1036.

Van Tassell, C. P., G. R. Wiggans, and I. Misztal. 2003. Implementation of a sire-maternal grandsire model for evaluation of calving ease in the United States. J. Dairy Sci. 86:3366-3373.

Van Vleck, L. D. 1981. Potential genetic impact of artificial insemination, sex selection, embryo transfer, cloning, and selfing in dairy cattle. Pages 222-242 in New Technologies in Animal Breeding. B. G. Brackett and G. E. Seidel Jr., ed. Academic Press, New York, NY.

Weigel, K. A. 2004. Exploring the role of sexed semen in dairy production systems. J. Dairy Sci. 87(E-Suppl.):E120-E130 